\title{
2. THE DISTRIBUTION OF GEOTHERMAL AND GEOCHEMICAL GRADIENTS NEAR SITE 501/504: IMPLICATIONS FOR HYDROTHERMAL CIRCULATION IN THE OCEANIC CRUST ${ }^{1}$
}

\author{
M. G. Langseth, ${ }^{2}$ M. J. Mottl, ${ }^{3}$ M.A. Hobart, ${ }^{2}$ and A. Fisher ${ }^{4}$
}

\begin{abstract}
A detailed survey of heat flow and geochemical gradients in pore water within a $10 \times 10 \mathrm{~km}$ area surrounding Site $501 / 504$ revealed a broad and undulating variation in heat flow. The average heat flow weighted by area is $216 \mathrm{~mW} / \mathrm{m}^{2}$, and individual values range from 166 to $391 \mathrm{~mW} / \mathrm{m}^{2}$. The highest values were found in three localized zones. Gradients of $\mathrm{Ca}^{2+}$ and $\mathrm{Mg}^{2+}$ in pore waters of the upper $12 \mathrm{~m}$ of sediment were found to be extremely high within these high heat-flow zones. The profiles of calcium and magnesium have a characteristic exponential shape due to upward vertical movement of pore water through the sedimentary layer. Flux rates as high as $6 \mathrm{~mm} / \mathrm{yr}$ were estimated from the shape of the curves.

The discovery of significant flux through the sediments implies that there are reduced pressure variations in the top of the igneous crust on the order of a few bars and that the pressure field relative to hydrostatic probably drives lateral flow in upper basement at rates of $10-30 \mathrm{~cm} / \mathrm{yr}$. The survey and subsequent drill data verify that this flow attenuates variations in temperature and pore-water chemistry in the upper few hundred meters of basement. The variations in heat flow, pore-water chemical gradients, and implied fluxes of pore water are associated with hydrothermal convection in basement at a lateral scale of $3.5-4 \mathrm{~km}$ that may penetrate deeply into the crust.
\end{abstract}

\section{INTRODUCTION}

One of the initial motivations for drilling on the flank of the Costa Rica Rift was to examine an area where the oceanic crust appears to have reached conductive equilibrium with the cooling lithosphere at a young age, about 5-6 Ma (Anderson and Hobart, 1976). Site surveys carried out prior to initial drilling of Hole 504B on Leg 69 indicated seafloor heat flow was high (about $200 \mathrm{~mW} / \mathrm{m}^{2}$ ) and close to the theoretically predicted value for lithosphere 6 m.y. old (Hobart et al., 1985; Langseth et al., 1983). The heat flow is also remarkably uniform compared to the variability typical of most mid-ocean ridge flanks. These results were to be expected considering the $200-300 \mathrm{~m}$ of pelagic sediment that completely cover basement in the area of the DSDP holes and apparently hydraulically decouple the igneous oceanic basement from the bottom water. Nonetheless, the first geothermal surveys indicated a low-amplitude variability.

A subsequent survey made in 1982 mapped seafloor geothermal and geochemical gradients in the vicinity of Site 501/504 to determine the scale and amplitude of a large lateral gradient in the pore-water chemistry of the sediment between the holes drilled on Leg 69 (Mottl et al., 1983). Geothermal measurements and piston core samples obtained during the 1982 survey were located accurately relative to the seafloor using a bottom transponder net. They revealed a sizeable variation in heat flow and pore-water chemical gradients at the scale of kilometers. Three of the piston cores showed measureable gradients in pore-water chemistry in the upper $15 \mathrm{~m}$ of seafloor sediment associated with anomalously high thermal gradients. The anomalous gradients are confined to a small area suggesting that pore waters might be moving upward through the sedimentary layer at rates sufficient to concentrate pore waters characteristic of the basement in the shallow sub-bottom.

\footnotetext{
${ }^{1}$ Becker, K., Sakai, H., et al., 1988. Proc. ODP, Init. Repts. (Pt. A), 111: College Station, TX (Ocean Drilling Program).

2 Lamont-Doherty Geological Observatory, Columbia University of New York

${ }^{3}$ Hawaii Institute of Geophysics, University of Hawaii, Honolulu.

${ }^{4}$ Rosenstiel School of Marine and Atmospheric Sciences, University of Miami.
}

Downhole measurements on Legs 69,70 , and 83 provided considerable evidence for subhydrostatic pressures in the igneous crust penetrated at Site 501/504. Penetrating the sedimentary layer initiated a strong downflow of water that maintained borehole temperatures nearly isothermal at bottom water temperatures to a sub-bottom depth of $350 \mathrm{~m}$ (Becker et al., 1985), and extrapolation of pressure records made in a sealed portion of Hole 504B indicated that subhydrostatic pressures existed prior to drilling (Anderson and Zoback, 1982).

\section{THE 1986 SURVEY}

The growing body of evidence that active thermal convection may be occurring in the basement below the sedimentary cover inspired a cruise on the Thompson to the area of Site 501/504 in 1986 to define the two-dimensional distribution of geothermal and geochemical gradients in the vicinity of the drill sites by making a systematic survey of the seafloor heat flow within a $10 \times 10 \mathrm{~km}$ area. The measurements were placed accurately in a square pattern with aid of an array of five bottom transponders. Over 270 individual vertical temperature gradient measurements were made during the survey, and each measurement is located to $\pm 20 \mathrm{~m}$. The maximum spacing between adjacent measurements is approximately $1 \mathrm{~km}$ (Fig. 1). Most of the gradient measurements were made using the LDGO digital heat-flow unit with a 5-m probe carrying up to 6 sensors along its length. An additional 24 measurements were made with a $2-\mathrm{m}$ probe provided by the University of Miami, and 8 thermal gradient measurements were made on piston cores using thermistor probes mounted along the core barrel. The instruments are capable of making multiple penetrations of the seafloor during a single lowering, and they transmit temperature data acoustically to the surface ship so that the results of each measurement can be assessed immediately.

Piston cores as long as $12 \mathrm{~m}$ were obtained in areas of anomalously high heat flow. Chemical analyses were made on pore waters squeezed from sediment samples taken at frequent intervals along the core. Analyses for calcium $\left(\mathrm{Ca}^{2+}\right)$, magnesium $\left(\mathrm{Mg}^{2+}\right)$, alkalinity, $\mathrm{pH}$, and chlorinity of the pore water were made as soon as possible after the cores were obtained. 


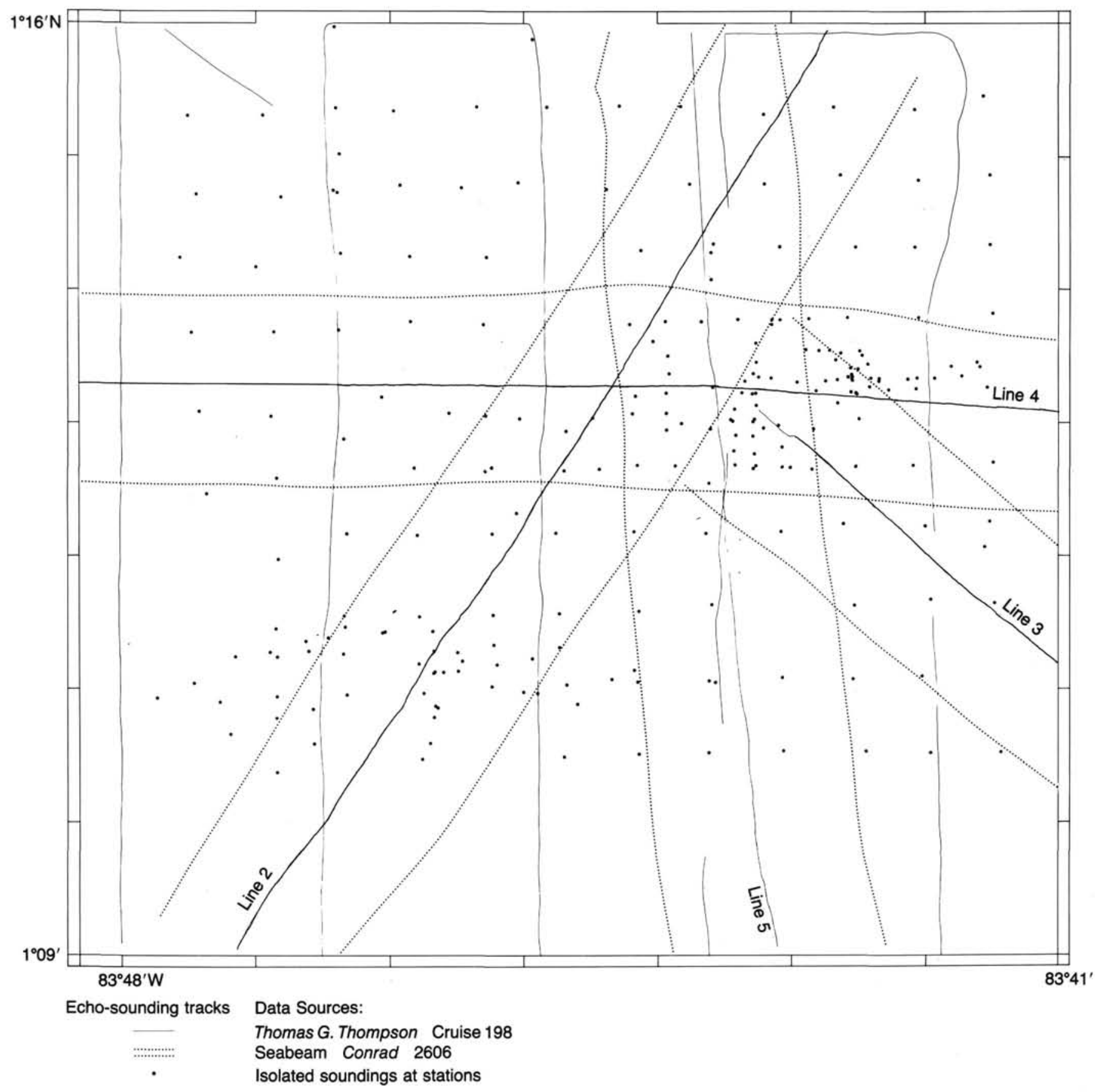

Figure 1. Data control for the bathymetric map in Figure 2.

To complement the station work, lines of single channel seismic (SCS) surveys using a water-gun source and $3.5-\mathrm{kHz}$ echo sounding were made within the area to define the bathymetry and sediment thickness more accurately and completely (Fig. 1). These lines were navigated within the bottom transponder array. Global Positioning System (GPS) provided continuous geodetically accurate navigation of the ship for parts of each day during the survey. The GPS also allowed the bottom transponder net to be located accurately with respect to a geodetic frame of reference. Five lines of GPS-navigated multibeam echo-sounding swaths that crossed the area of study were made available by Drs. J. Mutter and T. Brocher to aid in compiling the map shown in Figure 2.

\section{RESULTS \\ Bathymetry}

A contour map of bottom topography was constructed using only data positioned by GPS or bottom navigation (Fig. 2). The relief in the $10 \times 10 \mathrm{~km}$ area is remarkably subdued for a ridge flank. The variation is $\pm 60 \mathrm{~m}$ about a mean depth of $3450 \mathrm{~m}$. The contours define linear east-trending ridges and troughs primarily controlled by the basement topography, which is formed by tilted fault blocks with the steeper slope facing north.

A $3.5-\mathrm{kHz}$ sounding profile that runs north-south at $83^{\circ} 44^{\prime} \mathrm{W}$ is shown in Figure 3A. This profile illustrates the rounded nature of the topography and a prominent sub-bottom reflector at 


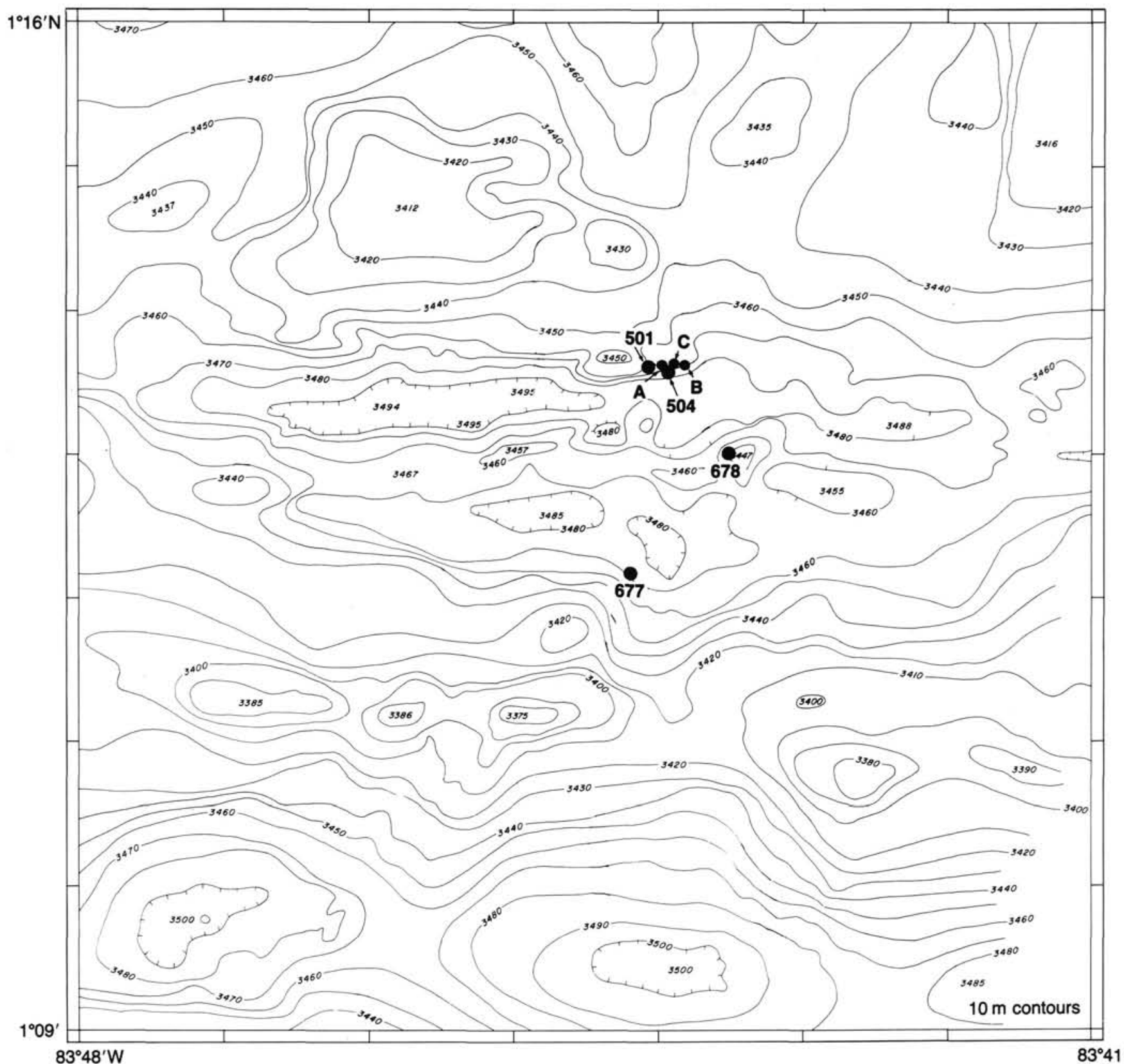

Figure 2. Contour map of seafloor bathymetry in the Site 501/504 area. Locations of Holes 501, 504, 504 A-C, Site 677, and Site 678 are also shown.

about $10 \mathrm{~m}$ depth that is much stronger than the bottom return. The sub-bottom reflection is from a several-centimeters-thick ash layer called the "Worzel Ash" which is prevalent throughout the area. Apparently the strength of this reflector compared to the seafloor echo causes the multibeam system to lock on to this reflector rather than the weak seafloor return and thus to record depths that are $10 \mathrm{~m}$ too deep. A 10-m discrepancy between the multibeam and $3.5-\mathrm{kHz}$ depths was frequently observed. Accordingly, the multibeam depths were adjusted upward by $10 \mathrm{~m}$ to prepare the contour map.

Drill Sites 501 and 504 are located on the southern slope of an asymmetric ridge which is the morphological expression of a tilted fault block. Site 677 is near the southern edge of a broad trough south of Site 504, and 677 is on a narrow ridge that rises to about $3460 \mathrm{~m}$ about $2 \mathrm{~km}$ southeast of Site 504 .

\section{Sediment Thickness and Basement Topography}

The SCS section shown in Figure 3B was made during the 1982 survey. It was digitally recorded with a water-gun source, and the display shown has been band pass filtered. The parameters used are given in the caption. The SCS data obtained on the Thompson had a poorer signal-to-noise ratio and provide less clear results.

The SCS section of Figure 3B shows that the sedimentary layer is 250 to $300 \mathrm{~m}$ thick, $\left(\mathrm{V}_{p}=1550 \mathrm{~m} / \mathrm{s}\right)$, and draped over the basement ridges. The layer thins over ridges and thickens in troughs due to a small amount of downslope movement. The increased depth to the "Worzel Ash" in the floor of the troughs (Fig. 3A) indicates that there is preferential deposition in the troughs. Layering within the sedimentary section results from 
A

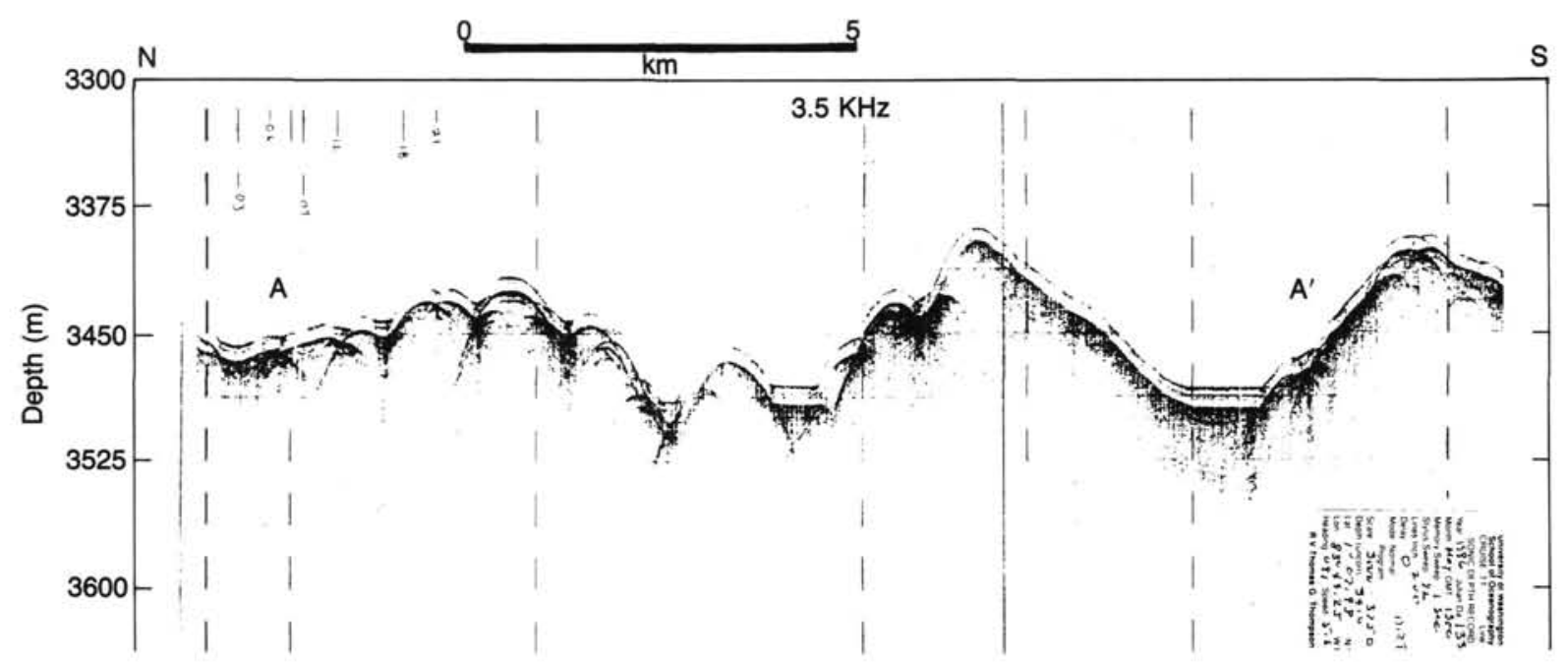

B

B

Single channel seismic section

Figure 3. A. Reproduction of the 3.5-kHz record along line A-A' (see Fig. 4). B. SCS section along line B-B' (Fig. 4). Processing parameters: band pass filter $30-220 \mathrm{~Hz}$, and time-varying gain.

ash layers, carbonate-rich zones (Mienert, 1983), and diagenetic fronts in the sediment. The sediments on the flank of the Costa Rica Rift in the vicinity of Site 501/504 are primarily biogenic pelagic oozes with two well-defined diagenetic fronts: a boundary between ooze and chalk at $140 \mathrm{~m}$ sub-bottom and a chalk and a cherty limestone boundary at about $234 \mathrm{~m}$ (Cann, Langseth, Honnorez, Von Herzen, and White, et al., 1983). These boundaries are visible as reflectors along most of the profile and are more or less conformable with the bottom topography. The chalk/cherty limestone boundary appears as a low-frequency smooth reflector just above basement that in many places makes it difficult to identify which reflector is associated with the top of basement. This problem and the poor quality of the SCS lines run in 1986 make it difficult to develop an accurate map of sediment thickness for the area.

\section{Geothermal Gradients and The Distribution of Heat Flow}

Heat-flow values for all of the stations taken on the 1986 and the 1982 cruises that fall within the area of the map are shown in Figure 4. The average of means within $1 \times 1 \mathrm{~km}$ squares is $216 \mathrm{~mW} / \mathrm{m}^{2}$, but there is considerable variation around this value as shown by the histogram in Figure 5 . The variation within the survey area is remarkably regular and easily contourable with a $50-\mathrm{mW} / \mathrm{m}^{2}$ contour interval with no values violating the contours. The contours define a broad east-trending undulation in seafloor heat flow that roughly follows the trend of the topography, with lows in the troughs and higher values on the ridges. However, there are clear exceptions to this pattern. Values vary from a low of 166 to a high of $391 \mathrm{~mW} / \mathrm{m}^{2}$. The latter value is nearly twice the average heat flow in the area. The maxima and minima are not evenly distributed; the lower values extend over broad regions, whereas the higher values are confined to a smaller percentage of the area as illustrated in the histogram (Fig. 5). The wavelength of the variation as defined by the north-south distance from maximum to maximum and minimum to minimum is $7-8 \mathrm{~km}$. The east-west trends of the heat-flow pattern are offset along a north-south line at $83^{\circ} 44^{\prime} \mathrm{W}$ by about half a wavelength. This line is roughly parallel to the plate flow directions and is marked by subtle but significant changes in mor- 


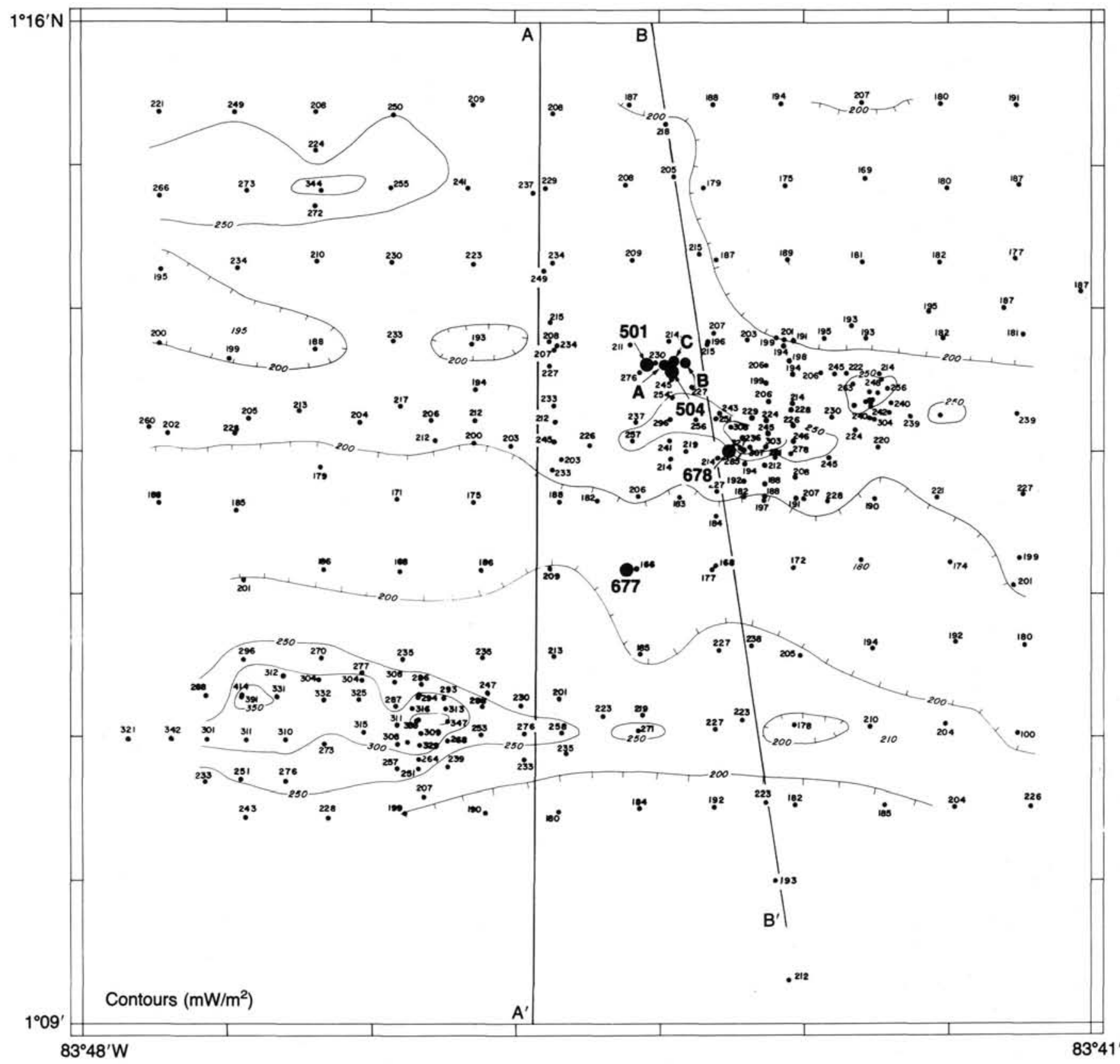

Figure 4. Preliminary heat-flow values in the Site 501/504 area. Drill hole locations are shown. Lines A-A' and B-B' are locations of profiles shown in Figure 3.

phological trends (Fig. 2), suggesting that this line may coincide with a small-offset transform fault. DSDP Sites 501/504 are drilled close to this line.

Figure 6 shows expanded maps of two areas of anomalously high heat flow where many closely spaced measurements were made to define these anomalies. A third anomalous area was found in the northwest corner of the area but was not surveyed in detail.

The pervasive cover of soft pelagic ooze allowed full penetration of the probe at most stations. Thus the gradient measurements are of uniformly high quality with four to six working thermistors buried in the sediment at each station. The temperature gradients are uniform with depth at all stations within the resolution of temperature measurement. The thermal conductivity in the upper $5 \mathrm{~m}$ of sediment is shown by numerous measurements on the piston cores (Fig. 7) to have low variability and no consistent trend with depth; consequently, heat flow is uniform with depth at all stations. This implies that any vertical flux of pore water must be less than about $5 \mathrm{~cm} / \mathrm{yr}$. (See Langseth and Herman 1981.) However the pore-water chemistry measurements provide clear evidence for pore-water flux in the areas of high heat flow at rates of several millimeters per year.

\section{Chemistry of Sediment Pore Waters}

Ten piston cores were taken in the Site 501/504 area on the 1982 Conrad cruise. Seven of these cores were located in areas of low or moderate heat flow (i.e., $<225 \mathrm{~mW} / \mathrm{m}^{2}$ ), and chemi$\mathrm{cal}$ analyses of pore waters squeezed from these cores revealed no detectable vertical gradient in calcium or magnesium. The remaining three cores were in an area where the heat flow is greater than $225 \mathrm{~mW} / \mathrm{m}^{2}$, and they exhibit small but well-documented gradients in $\mathrm{Ca}^{2+}$ and $\mathrm{Mg}^{2+}$ (Langseth and Mottl, 1982). 


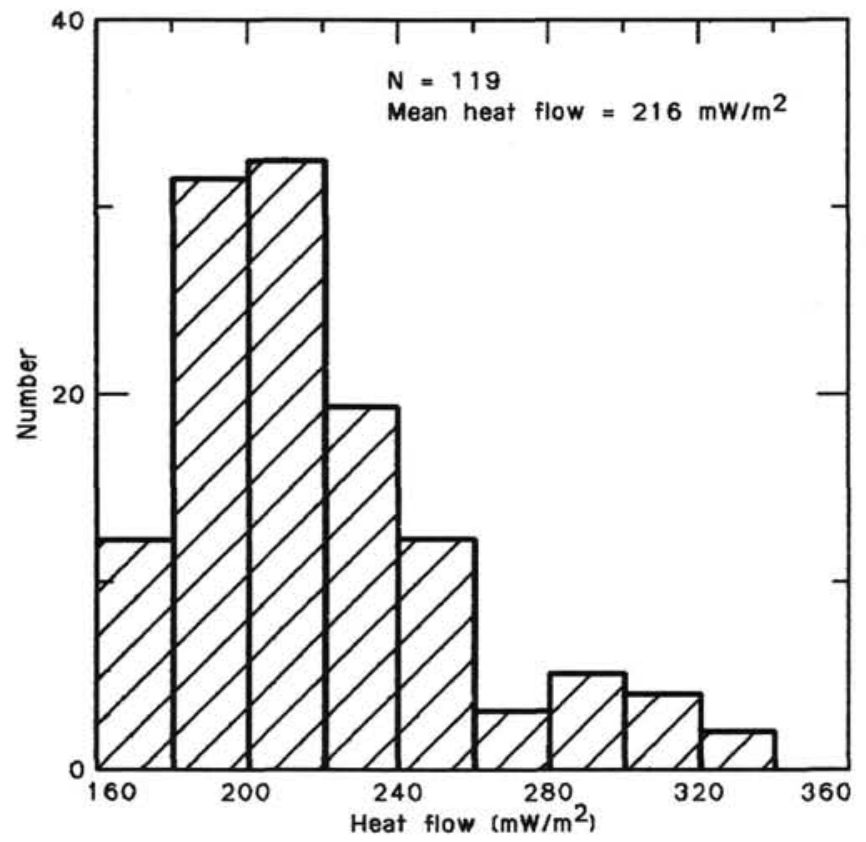

Figure 5. A histogram of average values of heat flow within $1 \times 1 \mathrm{~km}$ squares in the survey area of Figure 4.

We took 15 piston cores on the Thompson cruise in 1986, all located in or near high heat-flow anomalies (Fig. 6). The variations of $\mathrm{Ca}^{2+}$ and $\mathrm{Mg}^{2+}$ with depth in some of the cores are shown in Figure 8. The concentration profiles displayed in Figure 8 show a wide range of gradients from Core TT198-1(PC 1), which has no detectable gradient, to Core TT198-14(PC 14) in which the concentration of $\mathrm{Ca}^{2+}$ rises from $10 \mathrm{mmol} / \mathrm{kg}$ (the bottom water value) to greater than $50 \mathrm{mmol} / \mathrm{kg}$ in just $4 \mathrm{~m}$. Core TT198-14 was taken at the site of the highest heat flow observed in the area. Generally, there is a strong positive correlation of chemical gradient with thermal gradient.

The calcium and magnesium curves in Figure 8 are clearly complementary on a mole-by-mole basis. This behavior can be attributed to the fact that anomalous concentration gradients have a common source in the basaltic basement where magnesium is taken up and calcium released in the process of alteration (Lawrence et al., 1975; Lawrence and Gieskes, 1981). Most of the profiles exhibit an exponential decrease in gradient with depth becoming asymptotic to concentrations that are typical of pore fluids in highly altered basalt. The rapid exponential decay of the gradients with depth requires that there be a significant vertical advection of pore water to bring the basement concentrations so close to the seafloor. If the chemical link between seawater and basement were by diffusion through the sediment, the profiles would have a much smaller and nearly uniform gradient with depth.

Extremely high lateral gradients in the pore-water chemistry are also indicated by these data. In one area $2.4 \mathrm{~km}$ east of Hole 504 , for example, $\mathrm{Mg}^{2+}$ was found to decrease from 52 to $4 \mathrm{mmol} / \mathrm{kg}$ within the upper $7 \mathrm{~m}$ of sediment in three cores, whereas one core taken only $200 \mathrm{~m}$ to the south showed no detectable decrease in $\mathrm{Mg}^{2+}$ over its length of $7 \mathrm{~m}$.

\section{DISCUSSION}

\section{The Flux Rate of Pore Waters}

The concentration profiles in Figure $8 \mathrm{~A}$ and $\mathrm{B}$ provide an estimate of the rate of flux if the ionic diffusion coefficient is known. For a steady-state one-dimensional vertical flux, a dif- fusion rate that is uniform with depth, and no sources or sinks of the chemical species of interest in the region where the concentrations are measured, the following relation between flow rate and concentration vs. depth applies (Bredehoeft and Papadopulos, 1965):

$C(Z)=C_{1}+\left(C_{1}-C_{2}\right)\left(e^{-v \cdot z / D}-e^{-v \cdot z_{1} / D}\right) /\left(e^{-v \cdot Z_{1}}-e^{-v \cdot Z_{2} / D}\right)$

Where $\mathrm{C}(\mathrm{Z})$ is the concentration at depth $\mathrm{Z}, \mathrm{C}_{1}$ the concentration at $Z_{1}, C_{2}$ the concentration gradient at $Z_{2}$. V is the flux rate in $\mathrm{m} / \mathrm{s}$, and $\mathrm{D}$ is the diffusion coefficient in $\mathrm{m}^{2} / \mathrm{s}$. If we define $\mathrm{C}_{1}$ as the concentration at $\mathrm{Z}=0$ (the seafloor), and let $\mathrm{Z}_{2}$ go to infinity (equivalent to assuming that the depth to basement is very large compared to the 1 /e folding depth), then,

$$
\mathrm{C}(\mathrm{Z})=\mathrm{C}_{1}+\left(\mathrm{C}_{2}-\mathrm{C}_{1}\right)\left(1-\mathrm{e}^{-\mathrm{v} \cdot \mathrm{Z} / \mathrm{D}}\right)
$$

Curves corresponding to this equation (diffusion coefficient $=$ $0.95 \times 10^{-2} \mathrm{~m}^{2} / \mathrm{yr}, \mathrm{C}_{1}=0$, and $\mathrm{C}_{2}=45 \mathrm{mmol} / \mathrm{kg}$ ) are shown in Figure $8 \mathrm{C}$. Comparison of the observed and the model curves indicates that the flux required to produce the concentration profile of core TT198-14 is about $6 \mathrm{~mm} / \mathrm{yr}$. This rate is a factor of ten less than that required to produce nonlinearities in temperature profiles.

The curves of Figure $8 \mathrm{C}$ predict that flux at rates as low as a few tenths of a millimeter per year will produce detectable gradients of $\mathrm{Ca}^{2+}$ and $\mathrm{Mg}^{2+}$ in the upper $10 \mathrm{~m}$ of seafloor sediment. The profile of core TT198-2 is an example of a gradient associated with a flux that is only a fraction of a millimeter per year. At these rates it requires hundreds of thousands of years for the pore water to traverse the $200-300$-m-thick sedimentary layer. This suggests that the driving forces of the flow have persisted for at least this long.

The strong correlation of seafloor heat flow with the calcium and magnesium gradients is shown in Figure 9 where flow rates estimated from the concentration profiles are plotted against heat flow. A positive linear correlation is indicated. In Figure 10 two north-south transects across the high heat-flow anomalies studied in detail show that the highest pore-water flux rates are found near the peak of the geothermal anomaly. However, the higher heat flows in these are not due solely to the heat carried by the pore-water flow. Flow at a rate of $6 \mathrm{~mm} / \mathrm{yr}$ carries only $15 \%$ of the heat brought up from basement. The variation of seafloor heat flow depends more strongly on sediment thickness and basement temperature variations.

The pore-water chemistry analyzed at ODP Site 677 on Leg 111 , which was drilled in one of the areas of lowest heat flow (see Fig. 4), strongly suggested that there was a flow of water down through the $>300 \mathrm{~m}$ sedimentary cover. This exciting result answers a question posed by the TT198 survey as to the source of the pore waters being expelled in the heat-flow highs. The flux of pore water through the sediment is a form of sluggish hydrothermal circulation that links the top of the oceanic crust with ocean bottom water.

\section{Evidence For Hydrothermal Circulation in The Igneous Crust}

The flow of pore water through the sedimentary cover in the vicinity of Site 501/504 requires that significant pressure drops across the sediment layer exist in order to drive the flow. The amplitudes of the pressure drops could be determined with knowledge of the hydraulic resistance (the reciprocal permeability integrated with respect to depth over the sedimentary layer). This parameter has not yet been determined; however, an upper limit on the overpressure in basement below the high heat-flow zones is set by the sediment load, which, based on the porosity measurements of Wilkens and Langseth (1983), is about $10^{6} \mathrm{~Pa}(10$ 
A

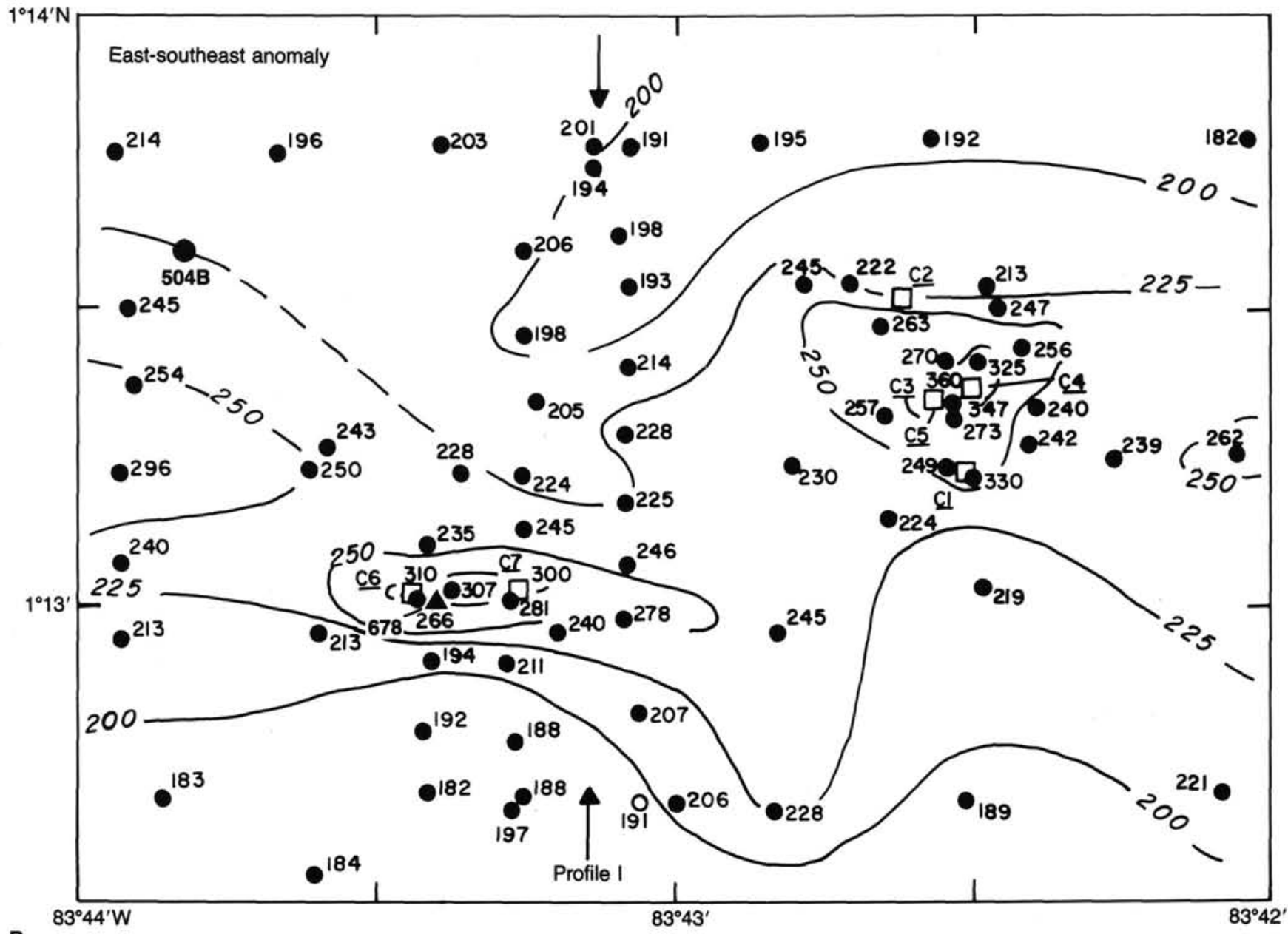

B

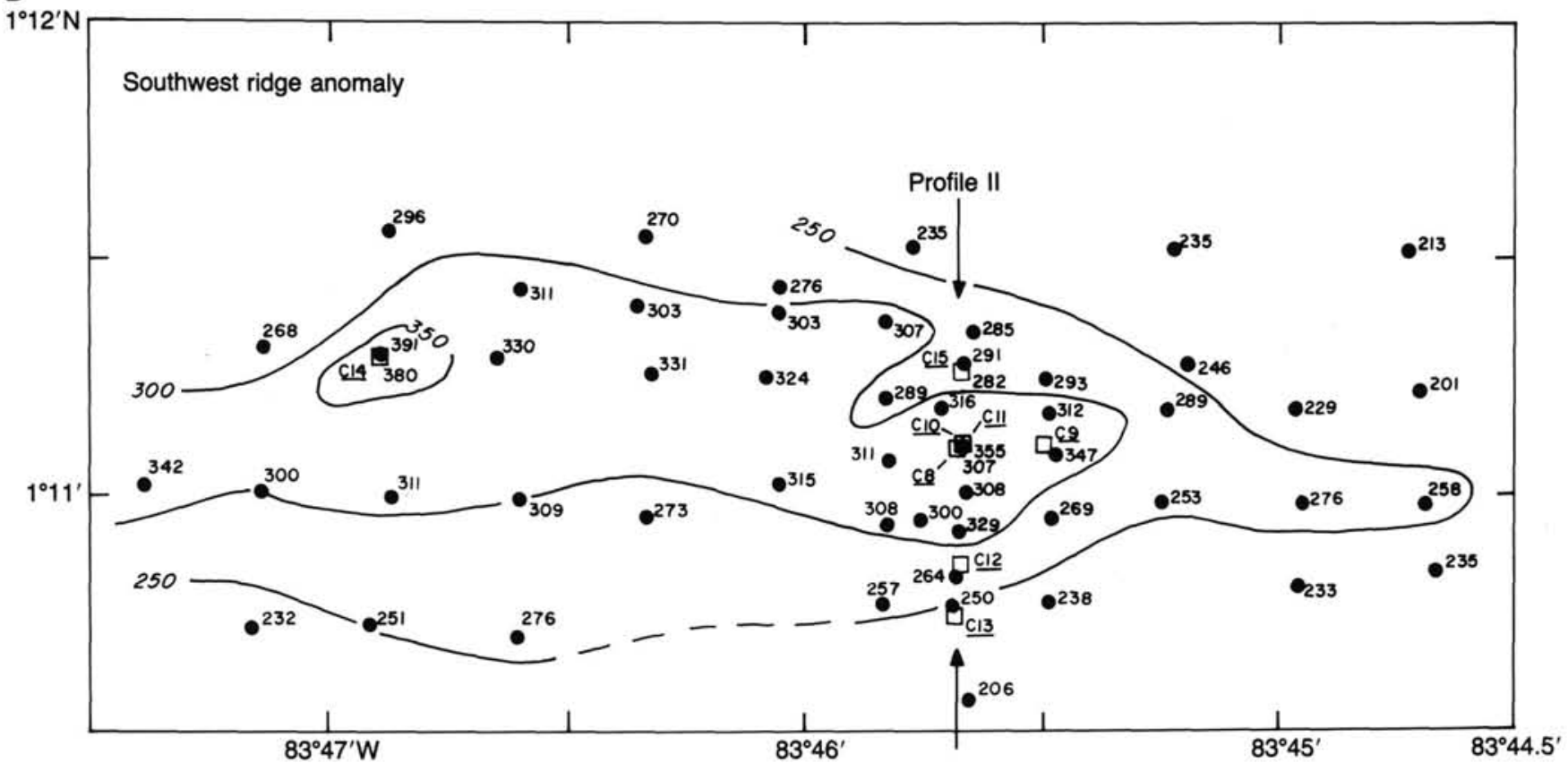

Figure 6. Large-scale maps of heat-flow values and piston core locations in the vicinity of the high heat-flow anomalies. A. The anomalous region east-southeast of Site 504. B. The anomalous region in the southwest corner of the map. Heat-flow measurement locations are shown by solid dots and core locations by open squares. 

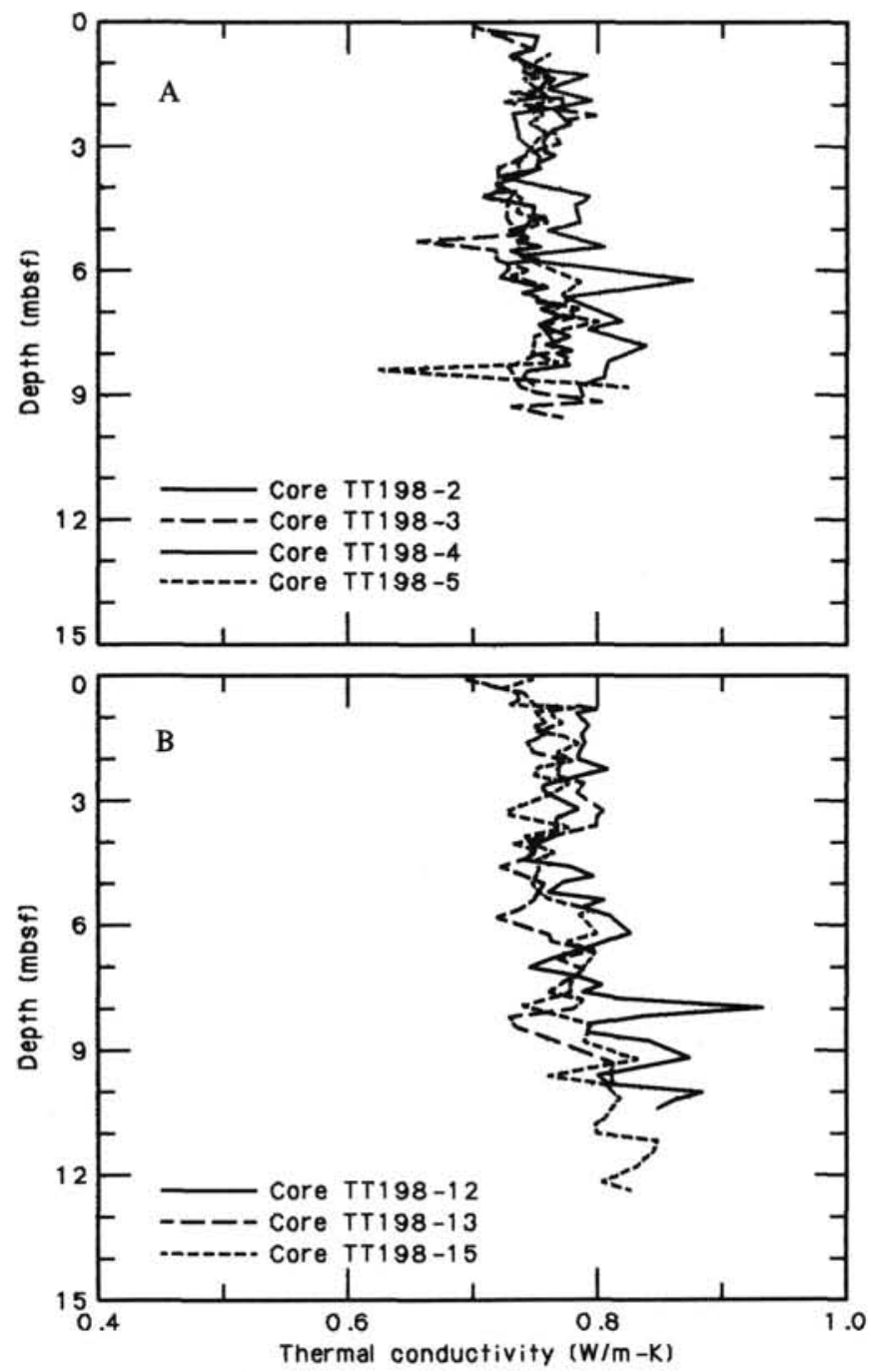

Figure 7. Thermal conductivity vs. depth measured on piston cores taken in the Site 501/504 area. A. Cores TT198-2 to -5 in main trough. B. Cores TT198-12, -13 , and -15 on southwest flank.

bars). Application of Darcy's law in one dimension indicates that the average permeability of the sedimentary layer must be at least $2 \times 10^{-17} \mathrm{~m}^{2}$ to permit flow of pore water at a rate of 6 $\mathrm{mm} / \mathrm{yr}\left(2 \times 10^{-10} \mathrm{~m} / \mathrm{s}\right)$. This value lies in the higher range of permeabilities of clays and oozes (Bryant et al., 1974). In view of these limits, pressure drops on the order of a few bars are required to drive the observed flow. These inferences agree with the subhydrostatic pressure of 8 bars that was measured by Anderson and Zoback (1982) in Hole 504B.

From the analysis above it is clear that lateral pressure variation on the order of a few bars in the upper part of basement are required to drive both upward and downward flux through the sediment cover. Furthermore from the correlation shown in Figure 9, the variation in pressure in the basement should closely mimic the variation of seafloor heat flow. Because of the relatively high permeability of the upper few hundred meters of igneous basement, $10^{-13}-10^{-14} \mathrm{~m}^{2}$ (Anderson and Zoback, 1982; Becker et al., 1985), the inferred pressure gradients would drive lateral pore water flow within the upper basement at rates on the order of centimeters per year.

The vertical advection of pore waters through the sediment provides strong evidence for convection within the igneous base- ment below the sedimentary layer. The seafloor heat-flow pattern suggests that the size of the convection cells is $3.5-4 \mathrm{~km}$ (half the wavelength of north-south heat-flow variation). Twodimensional finite amplitude analysis of thermal convection in an isotropic porous media indicates that the aspect ratio of single cells is not far from one (Ribando et al., 1976). If we assume that the analysis of such simple models applies to the oceanic crust with a stratified permeability ("Site 504" chapter, this volume), convection may penetrate to depths on the order of the thickness of the crust.

The inferred vigorous lateral flow of pore water in basement would also attenuate the variations in temperatures and porewater chemistry at the top of basement, since the flow would transport significant heat and homogenize the pore-water chemistry. The basement temperatures can be estimated from seafloor heat flow, sediment thickness, and the thermal conductivity vs. depth given by Wilkens and Langseth (1983). We can include the thermal effects of vertical pore-water flow by assuming the correlation between heat flow and pore-water flux in Figure 9 and applying a one-dimensional steady-state heat-flow model that includes advection. The results of such an analysis show that indeed the variation of temperature at the top of basement is less in terms of percent than the variation of seafloor heat flow. For example, the broad anomaly in the southwestern part of the survey area is to a large extent due to the thin sediment cover and to a lesser extent due to an increase in basement temperature. The chemistry of pore waters found near the sediment/basement contact at Sites 677 and 678 have nearly the same chemistry ("Site 677/678" chapter, this volume).

\section{CONCLUSIONS}

The picture of hydrothermal convection in the vicinity of Site 504B that emerges is:

1. The convection of pore fluids is largely confined to the igneous crust.

2. The pressure field associated with the convection is sufficient to drive a weak flow through the sedimentary cover that provides a sustained link between the basement and ocean bottom water.

3. The lateral dimensions of the convection cells are on the order of 3.5-4 km, suggesting that convective flow may extend through most of the crust.

4. The distribution of heat flow suggests that the convective flow is not two dimensional (i.e., simple rolls with axes that run east-west subparallel to the ridge axis or topographic trends). However, the cell axes are elongate in the east-west direction.

5. The upwelling and downwelling limbs of the convection cells are not symmetrically distributed. Downwelling limbs are found under a much larger percentage of the area surveyed as had been predicted by several theoretical models (e.g., Fehn et al., 1983).

6. Locations of the convection cells appear to have been fixed relative to the crust for the past few hundred thousand years at least.

The results of this survey show the extraordinary value of detailed surveys, particularly of geothermal and geochemical gradients in the vicinity of deep crustal holes. It is evident that if the detailed and incisive information provided by this survey were available before drilling began in this area, then more effective locations for drill sites could have been chosen, and the objectives of the drilling could have been better defined. The survey also shows that other exciting targets remain in the area, particularly for downhole measurements. 

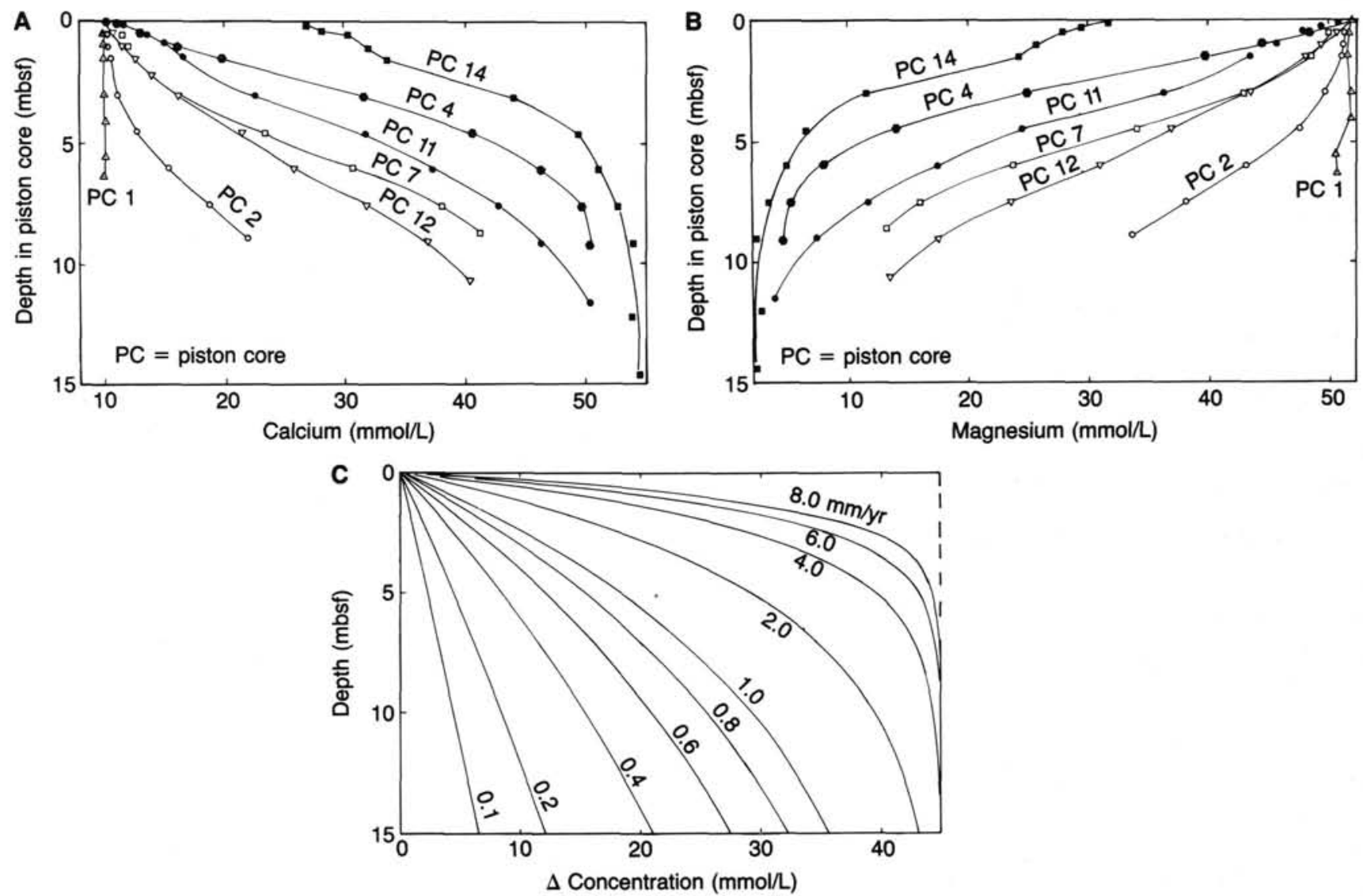

Figure 8. Selected profiles. A. $\mathrm{Ca}^{2+}$ vs. depth below seafloor. B. $\mathrm{Mg}^{2+}$ vs. depth below seafloor. C. Theoretical concentration curves vs. depth for various rates of flux (shown on each curve). The ionic diffusion coefficient is assumed to be $0.95 \times 10^{-2} \mathrm{~m}^{2} / \mathrm{yr}$.

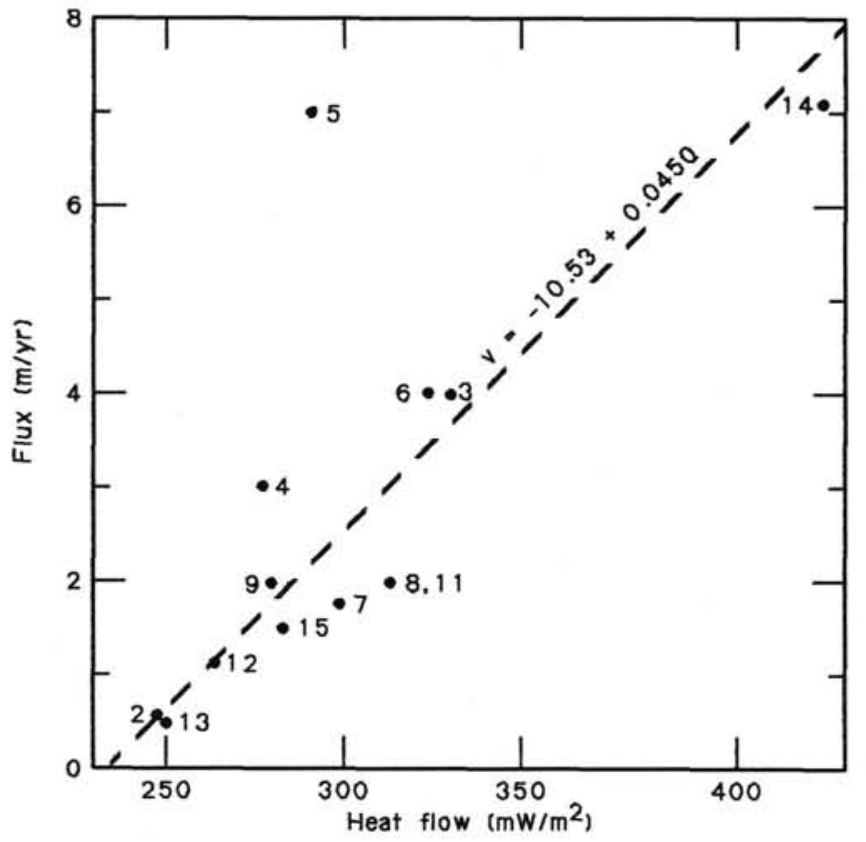

Figure 9. Estimated vertical pore-water flux vs. seafloor heat flow. The dashed line is fitted by eye.

\section{ACKNOWLEDGMENTS}

The field program and research that form the basis of this paper were supported by National Science Foundation grants OCE85-17013, OCE86-08261, and OCE85-16773. Special thanks are due the officers and crew of the Thompson for their patient and expert help in carrying out the demanding ship maneuvering and navigation to complete the nearly 300 stations in a 3 -week period. Tom Lehman provided experienced supervision during all deck operations. Drs. J. Mutter and T. Brocher kindly allowed us to use some of the multibeam echo-sounding data they obtained during Conrad cruise 2606. J. Miller of the University of Rhode Island provided help in the processing and interpretation of the multibeam data.

\section{REFERENCES}

Anderson, R. N., and Hobart, M. A., 1976. The relation between heat flow, sediment thickness and age in the Eastern Pacific. J. Geophys. Res., 81:1968-1989.

Anderson, R. N., and Zoback, M. D., 1982. Permeability, underpressures, and convection in the oceanic crust near the Costa Rica Rift, Eastern Equatorial Pacific. J. Geophys. Res., 87:2860-2868.

Becker, K., Langseth, M. G., Von Herzen, R. P., Anderson R. N., and Hobart, M. A., 1985. Deep crustal geothermal measurements, Hole 504B, Deep Sea Drilling Project Legs 69, 70, 83, and 92. In Anderson, R. N., Honnorez, J., Becker, K., et al., Init. Repts. DSDP, 83: Washington (U.S. Govt. Printing Office), 405-418.

Bredehoeft, J. D., and Papadopulos, I. S., 1965. Rates of vertical groundwater movement estimated from the earth's thermal profile. Water Resources Res., 2:325-328.

Bryant, N. R., Deflache, A. P., and Trabant, P. K., 1974. Consolidation of marine clays and sediments. In Indubitzen, A.L. (Ed.). Deep Sea Sediments (Vol. 2): New York (Plenum Press). 
Cann, J. R., Langseth, M. G., Honnorez, J., Von Herzen, R. P., White, S. M., et al., 1983. Init. Repts. DSDP, 69: Washington (U.S. Govt. Printing Office).

Fehn, U., Green, K. E., Von Herzen, R. P., and Cathles, L. M., 1983. Numerical models for the hydrothermal field at the Galapagos Spreading Center. J. Geophys. Res., 88:1033-1048.

Hobart, M. A., Langseth, M. G., and Anderson, R. N., 1985. A geothermal and geophysical survey on the south flank of the Costa Rica Rift: Sites 504 and 505. In Anderson, R. N., Honnorez, J., Becker, K., et al., Init. Repts. DSDP, 83: Washington (U.S. Govt. Printing Office), 379-404.

Langseth, M. G., and Herman, B. M., 1981. Heat transfer in the oceanic crust of the Brazil Basin. J. Geophys. Res., 86:10805-10819.

Langseth, M. G., Cann, J. R., Natland, J. H., and Hobart, M., 1983. Geothermal phenomena at the Costa Rica Rift: Background and objectives for drilling at Deep Sea Drilling Project Sites 501, 504, and 505. In Cann, J. R., Langseth, M. G., Honnorez, J., Von Herzen, R. P., White, S. M., et al. Init. Repts. DSDP, 69: Washington (U.S. Govt. Printing Office), 5-29.

Langseth, M. G., and Mottl, M. J., 1982. Geochemical and geothermal mapping of crustal circulation patterns near DSDP, Site 501/504, Trans. Am. Geophys. Union, 63:1116.
Lawrence, J. R., Gieskes, J. M., and Broecker, W. S., 1975. Oxygen isotope and cation composition of DSDP pore waters and the alteration of Layer II basalts. Earth Planet. Sci. Lett., 27:1-10.

Lawrence, J. R., and Gieskes, J. M. 1981. Constraints on water transport and alteration in the oceanic crust from the isotopic composition of pore water. J. Geophys. Res., 86:7924-7934.

Mienert, J., 1983. The importance of carbonate content in the acoustic stratigraphy of Panama Basin. Mar. Geol., 54:237-247.

Mottl, M. J., Lawrence J. R., and Keigwin, L. D., 1983. Elemental and stable-isotope composition of pore waters and carbonate sediments from Deep Sea Drilling Project Sites 501/504 and 505. In Cann, J. R., Langseth, M. G., Honnorez, J., Von Herzen, R. P., White, S. M., et al. Init. Repts DSDP, 69: Washington (U.S. Govt. Printing Office), 461-473.

Ribando, R. J., Torrence, K. E., and Turcotte, D. L., 1976. Numerical models of hydrothermal circulation in the oceanic crust, J. Geophys. Res., 81:3007-3012.

Wilkens, R. H., and Langseth, M. G., 1983. Physical properties of sediments of the Costa Rica Rift, Deep Sea Drilling Project Sites 504 and 505. In Cann, J. R., Langseth, M. G., Honnorez, J., Von Herzen, R. P., White, S. M., et al. Init. Repts. DSDP, 69: Washington (U.S. Govt. Printing Office), 659-673.
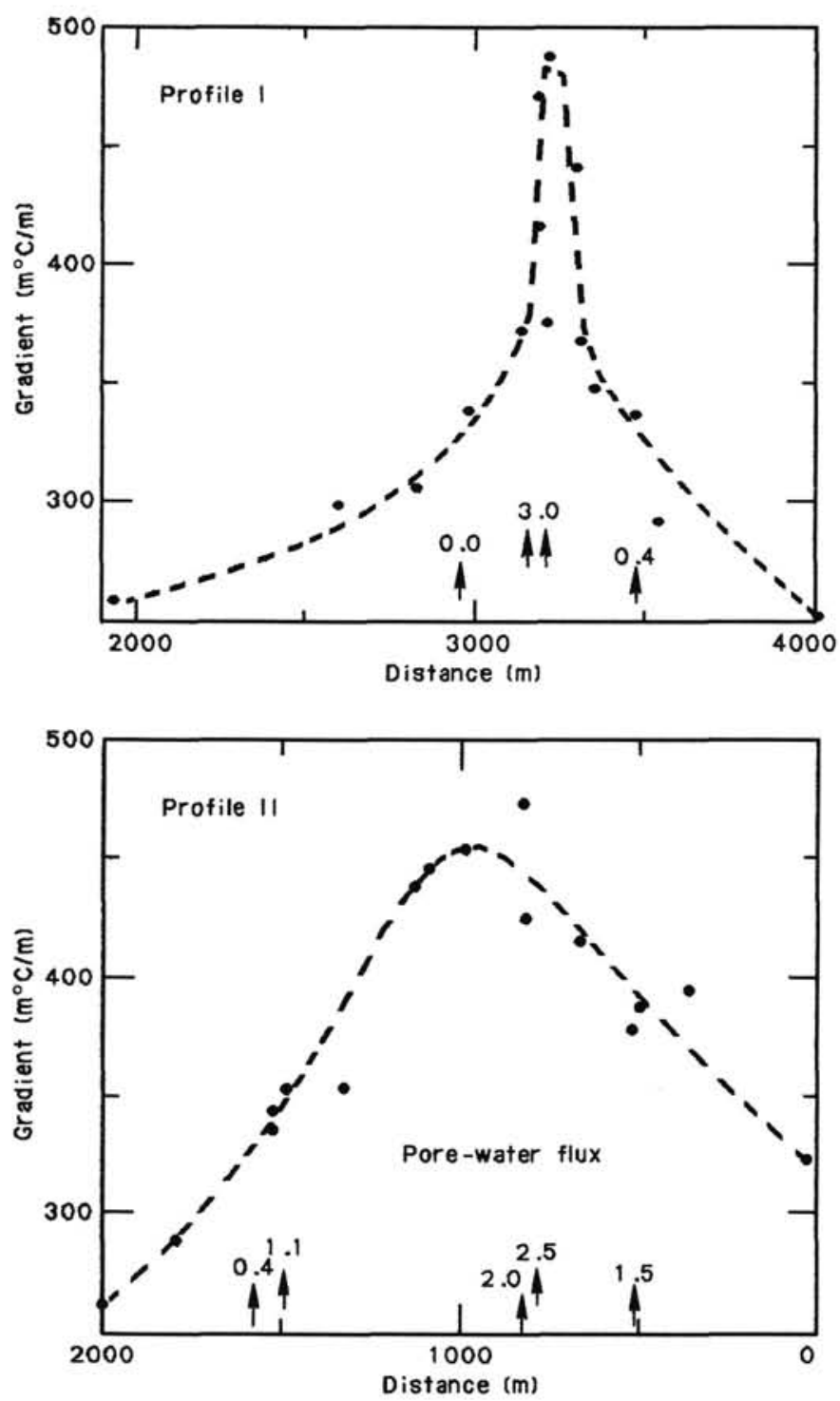

Figure 10. North-south profiles of heat flow and pore-water flux over the two anomalous regions shown in Figure 6. 